\title{
Cellular Action of Vasopressin in Medullary Tubules of Mice with Hereditary Nephrogenic Diabetes Insipidus
}

\author{
Brian a. Jackson, Richard M. Edwards, Heinz Valtin, and Thomas P. Dousa, \\ Nephrology Research Laboratories, Mayo Clinic and Foundation, Mayo Medical \\ School, Rochester, Minnesota 55901; and Department of Physiology, Dartmouth \\ Medical School, Hanover, New Hampshire 03755
}

A B S T RACT Our previous studies (1974. J. Clin. Invest. 54: 753-762.) suggested that impaired metabolism of cyclic AMP (cAMP) may be involved in the renal unresponsiveness to vasopressin (VP) in mice with hereditary nephrogenic diabetes insipidus (NDI). To localize such a defect to specific segments of the nephron, we studied the activities of VP-sensitive adenylate cyclase, cAMP phosphodiesterase (cAMPPDIE), as well as accumulation of cAMP in medullary collecting tubules (MCT) and in medullary thick ascending limbs of Henle's loop (MAL) microdissected from control mice with normal concentrating ability and from mice with hereditary NDI.

Adenylate cyclase activity stimulated by VP or by $\mathrm{NaF}$ was only slightly lower $(-24 \%)$ in MCT from NDI mice, compared with controls. In MAL of NDI mice, basal, VP-sensitive, and NaF-sensitive adenylate cyclase was markedly $(>-60 \%$ ) lower compared with MAL of controls. The specific activity of cAMP-PDIE was markedly higher in MCT of NDI mice compared with controls, but was not different between MAL of control and NDI mice. Under present in vitro conditions, incubation of intact MCT from control mice with VP caused a striking increase in cAMP levels $(>10)$, but VP failed to elicit a change in cAMP levels in MCT from NDI mice. When the cAMP-PDIE inhibitor 1methyl-3-isobutyl xanthine (MIX) was added to the above incubation, VP caused a significant increase in cAMP levels in MCT from both NDI mice and control mice. Under all tested conditions, cAMP levels in MCT of NDI mice were lower than corresponding values in control MCT. Under the present experimental setting, VP and other stimulating factors (MIX, cholera

Results were presented in part at the joint Japan-U. S. A. seminar "Biosynthesis, Secretion and Mechanism of Action of Vasopressin," Nikko, Japan, September 1979, and at the Fall American Physiologist Society meeting, October 1979, New Orleans, La. 1979. Physiologist. 22: 33.

Received for publication 22 October 1979 and in revised form 24 March 1980. toxin) did not change cAMP levels in MAL from either control mice or from NDI mice.

The results of the present in vitro experiments suggest that the functional unresponsiveness of NDI mice to VP is perhaps mainly the result of the inability of collecting tubules to increase intracellular cA.MP levels in response to VP. In turn, this inability to increase cAMP in response to VP is at least partly the result of abnormally high activity of cAMP-PDIE, a somewhat lower activity of VP-sensitive adenylate cyclase in MCT of NDI mice, and perhaps to a deficiency of some other as yet unidentified factors. The possible contribution of low VP-sensitive adenylate cyclase activity in MAL of NDI mice to the renal resistance to VP remains to be defined.

\section{INTRODUCTION}

One animal model that phenotypically closely resembles human hereditary nephrogenic diabetes insipidus (NDI) ${ }^{1}$ is a strain of mouse (so-called DI $+/+$ severe) with an inherited, vasopressin (VP)-resistant urinary concentrating defect (1-4). Because administration of VP to NDI mice fails to increase osmolality of hypotonic urine $(2,3)$, these functional features indicate that collecting tubules failed to increase water permeability in response to the hormone. It is well established that the hydroosmotic effect of VP in collecting tubules (5-8) is mediated by adenosine $3^{\prime}, 5^{\prime}$-cyclic monophosphate (cAMP) $(5-7)$, and we have previously investigated the possibility that unresponsiveness to VP in NDI mice might be the

\footnotetext{
${ }^{1}$ Abbreviations used in this paper: AVP, [8-arginine]vasopressin, cAMP-PDIE, cAMP phosphodiesterase; Gpp(NH)p, 5'-guanylimidodiphosphate; GTP, guanosine 5'triphosphate; MAL, medullary thick ascending limb of Henle's loop; MCT, medullary collecting tubule; MIX, 1methyl-3-isobutyl xanthine; NDI, nephrogenic diabetes insipidus; RIA, radioimmunoassay; VP, vasopressin; \% relative.
} 
result of a defect in VP-dependent cAMP metabolism $(4,9,10)$.

In our previous studies (4), we investigated several known (or hypothetical) biochemical components involved in the cellular action of VP in a cell-free system (4). In washed membrane fractions prepared from the renal medulla (outer and inner medulla taken together), stimulation of adenylate cyclase by VP was lower in preparations from NDI mice than from control mice with an intact urinary concentrating mechanism (4). Because the responsiveness of renal medullary adenylate cyclase to VP in NDI mice was diminished but not absent, it remained an open question whether such a partial deficiency could be the cause of complete functional unresponsiveness to VP $(9,10)$.

Current advances in methodology now enable us to determine the activity of adenylate cyclase (11), cAMP phosphodiesterase (CAMP-PDIE) (12), and cAMP content $(13,14)$ in individual segments of the nephron. In most mammalian species, including mice (15), VP-sensitive adenylate cyclase was found not only in collecting tubules and ducts, as expected, but also in the ascending limb of Henle's loop (16). Although the function of VP (and by extension, of the VP-dependent cAMP system) in the ascending limb of Henle's loop is not yet established, recent observations suggest that VP stimulates solute transport out of the lumen of thick medullary ascending limbs of Henle's loop, at least in the mouse and rat kidney (16-19), thus enhancing dilution of tubular fluid and build-up of solute gradient in the interstitium.

To define and localize defects in the cellular action of VP in NDI mice, we have now investigated key components of VP-sensitive cAMP metabolism in two distinct sites of VP action, namely, the medullary collecting tubules (MCT) and the medullary thick ascending limb of Henle's loop (MAL). These two nephron segments were microdissected from the outer medulla of mice with hereditary NDI, and control mice with intact urinary concentrating function.

The results have revealed several specific alterations in VP-dependent cAMP metabolism in MCT and MAL of NDI mice; these alterations may be the biochemical basis for the resistance of NDI mice to the antidiuretic effect of VP in vivo.

\section{METHODS}

Experimental animals were adult mice of either sex. As in our previous study (4), the so-called DI $+/+$ severe strain of mice with fully expressed NDI (2-4) were compared with the the VII +/+ strain, which have normal concentrating ability and serve as controls. These two strains are subsequently referred to in the text as "NDI mice" and "control mice," respectively. All animals were raised in the Department of Physiology, Dartmouth Medical School (Hanover, $\mathrm{N}$. H.) under conditions identical to those thoroughly described in our previous communication (4). After shipment by air to Rochester, Minn., and before experimentation, all animals were maintained for at least $10 \mathrm{~d}$ in an air-conditioned room $\left(21^{\circ}-25^{\circ} \mathrm{C}\right)$ and allowed free access to tap water and standard diet (Purina Laboratory Rat Chow, Ralston Purina Co., St. Louis, M. O.). Urine osmolality of control mice ranged around $2,500 \mathrm{mosmol} / \mathrm{kg} \mathrm{H}_{2} \mathrm{O}(3,4)$, whereas that of NDI mice averaged $217 \pm 28 \mathrm{mosmol} / \mathrm{kg} \mathrm{H}_{2} \mathrm{O}$ (mean $\pm \mathrm{SEM}$ ); in fact, each DI $+1+$ severe animal was classified in Hanover, N. H., on the basis of its genetic background and the fact that it excreted urine that was hypotonic to plasma.

Preparation of tissue samples. Tubular segments were prepared from control and NDI mice using the procedure described in principle by Morel et al. (11), with several minor modifications. Mice were lightly anesthetized with phenobarbital ( $12 \mathrm{mg} / 100 \mathrm{~g}$ body wt) and the aorta was cannulated retrogradely with polyethylene PE-10 tubing (Clay Adams, Div., Parsippany, N. J.), the tip being placed just distal to the branching of the left renal artery. Both kidneys were perfused to complete blanching with $10 \mathrm{ml}$ of heparinized (heparin concentration $20 \mathrm{USP} \mathrm{U} / \mathrm{ml}$ ) "collagenase medium" (composition specified below) at the rate of $1 \mathrm{ml} /$ min. After the perfusion, both kidneys were quickly removed and sliced with a razor blade along the corticomedullary axis. The slices were then incubated in aerated collagenase medium at $35^{\circ} \mathrm{C}$ for $25 \mathrm{~min}$. After incubation, the slices were thoroughly rinsed in ice-cold "microdissection medium" (composition given below) and transferred to Petri dishes for microdissection. All subsequent steps, including microdissection, were performed at $0^{\circ}-4^{\circ} \mathrm{C}$. Segments of MAL and MCT, 0.5-1.0 mm long, were carefully teased out from the inner stripe of the outer medulla with sharpened steel needles using a stereomicroscope (magnification $30 \times$ ). MAL and MCT were identified using the criteria described by Morel et al. $(11,20)$. In general, MAL have smooth sharp walls, whereas MCT appear granular and have irregular borders. In addition, the MAL frequently has a segment of thin ascending limb attached to it, which also aids in identification. The thin segment is cut off before transfer. Appearance of tubules from NDI mice was similar to that of controls, except that MCT appeared slightly distended in some nephrons from NDI mice. The external diameters of tubules were determined from photographs. MAL from control and NDI mice did not differ in external diameter; however, outer diameters of MCT from NDI mice were significantly greater than those from control mice (Table I). Dissected segments were aspirated in a small droplet of microdissection medium and transferred either directly onto concave bacteriological slides or onto small fragments $\left(\sim 3 \mathrm{~mm}^{2}\right)$ of glass cover slip, depending upon the assay to be performed. In general, two to three segments of MCT or MAL were pooled (combined length up to $2-3 \mathrm{~mm}$ ) in $<1 \mu$ l of microdissection medium to constitute one sample. All the samples of tubule segments were then photographed (magnification $40 \times$ ) and tubule lengths were measured from photographs using a planar measure. After the segments were photographed, samples were kept at $0^{\circ}-4^{\circ} \mathrm{C}$ before incubations or assays to be performed immediately, or before freezing for storage.

\section{Assays}

To minimize day-to-day variations between assays and preparative procedures, and to allow paired comparisons where appropriate, tubules from control and NDI mice were dissected, incubated, and assayed simultaneously. Likewise, when the actions of hormones and drugs were studied, tubules from the same animal were incubated with or without test agents within the same experiment.

Enzyme assays. Because tubular cells are, in general, rela- 
TABLE I

External (Outer) Tubular Diameter and Protein Content of MCT and of MAL from Normal (Control) Mice and Mice with NDI

\begin{tabular}{|c|c|c|c|}
\hline & Control mice & NDI mice & $P$ value $*$ \\
\hline \multicolumn{4}{|c|}{$\begin{array}{l}\text { External tubular } \\
\text { diameter, } \mu m\end{array}$} \\
\hline MCT & $\begin{array}{c}32.9 \pm 0.6 \neq \\
(33)\end{array}$ & $\begin{array}{c}43.6 \pm 0.6 \\
(38)\end{array}$ & $<0.001$ \\
\hline MAL & $\begin{array}{c}23.7 \pm 0.5 \\
(43)\end{array}$ & $\begin{array}{c}24.6 \pm 0.6 \\
(.30)\end{array}$ & NS \\
\hline \multicolumn{4}{|c|}{$\begin{array}{l}\text { Protein content, } \\
\mu \mathrm{g} / \mathrm{mm}\end{array}$} \\
\hline MCT & $\begin{array}{c}0.09 \pm 0.005 \ddagger \\
(25)\end{array}$ & $\begin{array}{c}0.13 \pm 0.009 \\
(27)\end{array}$ & $<0.001$ \\
\hline MAL & $\begin{array}{c}0.10 \pm 0.006 \\
(30)\end{array}$ & $\begin{array}{c}0.12 \pm 0.006 \\
(35)\end{array}$ & $<0.025$ \\
\hline
\end{tabular}

* For significance of difference between control mice and NDI mice; $t$ test.

$\ddagger$ Denotes mean $\pm \mathrm{SEM}$; number of samples is indicated in parentheses.

tively impermeable to nucleotides (11), they were first disrupted before enzyme assays (adenylate cyclase, cAMPPDIE) by a combination of freezing and hypoosmotic shock (11). The microdissection medium was aspirated from each sample and replaced with $0.5 \mu \mathrm{l}$ "hypoosmotic medium" (composition given below). All samples were then frozen rapidly by placing them on a block of dry-ice and stored at $-80^{\circ} \mathrm{C}$ overnight. Before assay, samples were allowed to thaw at $4^{\circ} \mathrm{C}$ and then used for determinations of enzyme activities.

Adenylate cyclase activity was measured according to a modification of the method of Morel et al. (11, 20, 21). Samples of tubules (0.1-0.2 $\mu \mathrm{g}$ protein/sample) were incubated at $30^{\circ} \mathrm{C}$ for $30 \mathrm{~min}$ in a final volume of $5.5 \mu$ l consisting of the following (final concentrations): $0.25 \mathrm{mM}\left[\alpha^{32}\right.$-P]ATP $\left(5-6 \times 10^{6} \mathrm{cpm} / \mathrm{sample}\right), 1 \mathrm{mM}$ cAMP, $3.8 \mathrm{mM} . \mathrm{MgCl}_{2}, 0.25$ $\mathrm{mM}$ EDTA, $100 \mathrm{mM}$ Tris $\mathrm{HCl}, 20 \mathrm{mM}$ creatine phosphate, and $1 \mathrm{mg} / \mathrm{ml}$ creatine kinase, $\mathrm{pH} 7.4$, with or without addition of hormones or other test substances as appropriate. The reaction mixture was sealed water-tight between two vaselinecoated concave slides and immersed in a constant temperature water bath $(11,20,21)$. The reaction was stopped by addition of $150 \mu \mathrm{l}$ "stop solution" consisting of $3.3 \mathrm{mM}$ ATP, $5 \mathrm{mM}$ cAMP, $50 \mathrm{mM}$ Tris $\mathrm{HCl}(\mathrm{pH} 7.6)$, and $\left[{ }^{3} \mathrm{H}\right] \mathrm{cAMP}\left(8 \times 10^{3}\right.$ $\mathrm{cpm} / \mathrm{sample}$; to determine recovery). Products were separated according to the method of Salomon et al. (22) using Dowex50 and aluminum oxide columns (Dow Chemical Co., Midland, Mich.); average recovery of cAMP was $61.4 \pm 0.4 \%$. Specific activity of adenylate cyclase was expressed in femtomoles of CAMP formed per $30 \mathrm{~min}$, either per millimeter of tubule length, or per microgram of tubular protein.

cAMP-PDIE activity was measured using an assay system employed previously for glomeruli and mixed cortical tubules (22), but adapted for small sample size (12). Tubular segments $(0.1-0.2 \mu \mathrm{g}$ protein/sample) were pretreated by freezing in hypoosmotic medium as described above for adenylate cyclase. Samples were incubated for $10 \mathrm{~min}$ at $37^{\circ} \mathrm{C}$ in a final volume of $5 \mu \mathrm{l}$ consisting of $10 \mathrm{mM} \mathrm{MgSO}_{4}, 0.1 \mathrm{mM}$ EDTA,
$50 \mathrm{mM}$ Tris $\mathrm{HCl}, \mathrm{pH} 8.0$ (Mg-EDTA-Tris buffer), with a final substrate concentration of $1 \mu \mathrm{M}\left[{ }^{3} \mathrm{H}\right] \mathrm{cAMP}\left(3 \times 10^{5} \mathrm{cpm}\right)$.

The reaction was terminated by addition of two successive $50-\mu \mathrm{l}$ aliquots of Mg-EDTA-Tris buffer, which were quickly transferred to glass test tubes $(12 \times 75 \mathrm{~mm})$. All test tubes were immediately immersed in a boiling water bath for $3 \mathrm{~min}$. Tubes were then cooled by placing them on ice and $50 \mu \mathrm{l}$ of 5 '-nucleotidase (rattlesnake venom from Crotalus atrox; 1 $\mathrm{mg} / \mathrm{ml}$ ) was added to each tube and incubated for a further $15 \mathrm{~min}$ at $37^{\circ} \mathrm{C}$, as in our previous studies $(7,23)$. Nucleotides were separated from nucleosides on QAE-Sephadex columns $(7,23)$ as described by Wells et al. (24).

In preliminary experiments it was determined that, under the conditions described above, cAMP hydrolysis is linearly proportional to tubular length (up to at least a total of $3 \mathrm{~mm} /$ sample) and also linearly proportional to time (up to at least $20 \mathrm{~min}$ ). This applies both tor MCT and MAL from either control or NDI mice. Consequently, specific activity of cAMPPDIE was expressed in femtomoles of cAMP hydrolyzed per min, either per millimeter of tubule length, or per micogram tubular protein. cAMP-PDIE was not affected by storage for $24 \mathrm{~h}$ at $-80^{\circ} \mathrm{C}$.

Incubation of tubules for determination of cAMP content. When testing the effect of hormones and drugs on cAMP accumulation, freshly dissected tubular segments $(3-4 \mathrm{~mm}$ pooled total length per one sample; more than needed for enzyme assay) were placed on fragments of glass cover slips $\left(\sim 3 \mathrm{~mm}^{2}\right)$ that were placed on concave bacteriological slides and photographed. The microdissection medium was aspirated from samples with a micropipette and replaced with $2.0 \mu \mathrm{l}$ of "modified Krebs-Ringer buffer" (composition given below) with or without hormone and/or drugs. While still on fragments of glass coverslip, the samples were then sealed water-tight between two vaseline-coated concave bacteriological slides and incubated in a water bath at $30^{\circ} \mathrm{C}$ for $20 \mathrm{~min}$. In each experiment, samples of MCT and MAL from both control and NDI mice were always incubated at the same time and under exactly the same conditions. At the end of the incubation period, the reaction was stopped by placing the slides with samples on a block of dry ice. This procedure causes instant freezing $(<1 \mathrm{~s})$ mainly because of the small sample mass; consequently, use of precooled stainless steel clamps and liquid $\mathrm{N}_{2}$, required for larger amounts of tissue (25), is not necessary. The samples, still frozen on glass cover slip fragments, were quickly transferred with forceps into the bottom of polyethylene radioimmunoassay (RIA) tubes (12 $\times 75 \mathrm{~mm}$ ) and $50 \mu \mathrm{l}$ of $5 \mathrm{mM} \mathrm{HCl}$ was added. The tubes were immediately placed in a boiling water bath for $5 \mathrm{~min}$, then cooled, and $50 \mu \mathrm{l}$ of $100 \mathrm{mM}$ sodium acetate buffer $(\mathrm{pH}$ 6.2) was added to each tube. The samples were then frozen and stored at $-20^{\circ} \mathrm{C}$ for up to $24 \mathrm{~h}$, until assayed for cAMP content by RIA.

Determination of cAMP content. The content of cAMP was determined by RIA as described in detail in our recent communications $(26,27)$. Samples, dissolved in acetate buffer (see above), and cAMP standards were first acetylated as described by Frandsen and Krishna (28), in a way analogous to our previous study (26). Acetylated samples and cAMP standards were incubated with anti-cAMP antibodies and ${ }^{125}$ I-succinyl-cyclic AMP methyl-ester for $16-24 \mathrm{~h}$ at $4^{\circ} \mathrm{C}$. Free and bound antigens were separated by centrifugation at $7,000 \mathrm{~g}$ for $20 \mathrm{~min}(26,27)$. Radioactivity of the samples was counted in a Searle analytical gamma counter, model 1285 (Searle Radiographics Inc., Des Plaines, Ill.). The specificity and validity of this modification of the RIA were detailed in our recent report (26). Because tubules were transferred to RIA tubes together with the incubation medium, cAMP content represents the sum of cAMP contained in 
tubular cells plus that which leaked into the incubation medium. Recovery of cAMP can be assumed to be complete because the tubules were transferred from incubation chambers directly into the RIA test tubes along with the fragments of cover slips on which they were incubated, and all subsequent steps (solubilization, acetylation, and RIA) were performed in these tubes.

Expression and evaluation of results. In most previous studies on adenylate cyclase activity in tubular segments, results were expressed per unit length of the tubule $(11,15$, $16,20,21)$. It is possible, however, that enzyme activities or cAMP levels, when corrected for protein content, may more closely reflect the situation in vivo, especially because protein content and, in the case of MCT also, outer diameter differ between control and NDI mice (Table I). Therefore, results have been presented both per millimeter tubular length (in the tables) and per micogram of protein in the sample (in the figures). The latter was calculated by multiplying the number of millimeters of total pooled tubular length in the sample by the appropriate factor for protein content (microgram per millimeter), as listed in Table I.

Because protein and enzyme activities or cAMP content cannot be measured in the same tubule sample, the average protein content per unit length was determined on a separate series of MAL and MCT. Frozen microdissected tubule samples were dissolved in $10 \mu$ l of $1 \%$ sodium dodecyl sulfate $(7,23,26,27)$, and protein content was determined by a modification of the colorimetric method of Lowry (29), similar to that used for protein determination in micropuncture samples (30). Final volume was $90 \mu \mathrm{l}$; using this modification for very small samples, quantities as low as $0.2 \mu \mathrm{g}$ protein/sample could be accurately determined.

As in rat kidney $(12,13)$, in both mouse MCT and MAL the protein content was directly proportional to tubule length. Tubule length correlated with protein content in MCT $(r$ $=0.68 \pm 0.14 ; P<0.001)$ and for MAL $(r=0.73 \pm 0.105 ; P$ $<0.001)$. Protein content per millimeter of MAL is almost identical to that detected in rat kidney MAL (13) and to the value reported for rabbit MAL (11). Likewise, the protein content of mouse MCT was similar to that of rat MCT (13) and lower than the protein content reported for rabbit cortical collecting tubules $(11,31)$. The outer diameter of MCT was larger than that of MAL (Table I); the difference was less than that reported for rat nephron (32). Both the outer diameter and protein content of MCT was significantly higher in NDI mice (Table I).

The data were evaluated statistically by $t$ test for either paired or group comparisons as appropriate, and as specified under Results. $P$ values $>0.05$ were considered to be nonsignificant.

\section{Solutions and materials}

The microdissection medium was a modified Hank's solution, basically as described by Imbert et al. (19), consisting of (in final concentrations): $137 \mathrm{mM} \mathrm{NaCl}, 5 \mathrm{mM} \mathrm{KCl}, 0.8 \mathrm{mM}$ $\mathrm{MgSO}_{4}, 0.33 \mathrm{mM} \mathrm{Na}_{2} \mathrm{HPO}_{4}, 1.0 \mathrm{mM} \mathrm{MgCl}, 10 \mathrm{mM}$ Tris- $\mathrm{HCl}$, $0.25 \mathrm{mM} \mathrm{CaCl}_{2}, \mathrm{pH} 7.4$. The composition of the collagenase medium was identical to that of the microdissection medium except that the $\mathrm{CaCl}_{2}$ concentration was $1 \mathrm{mM}$ and it included collagenase $(0.1 \% \mathrm{wt} / \mathrm{vol})$ and bovine serum albumin $(0.1 \%$ wt/vol). The hypoosmotic medium contained (in final concentrations): $1 \mathrm{mM} \mathrm{MgCl}, 0.25 \mathrm{mM}$ EDTA, $0.1 \%$ bovine serum albumin (wt/vol), and $1 \mathrm{mM}$ Tris- $\mathrm{HCl}, \mathrm{pH}$ 7.4. Modified Krebs Ringer buffer contained $140 \mathrm{mM} \mathrm{NaCl}, 5 \mathrm{mM} \mathrm{KCl}$, $1.2 \mathrm{mM} \mathrm{MgSO}, 0.8 \mathrm{mM} \mathrm{CaCl}, 10 \mathrm{mM}$ sodium acetate, $10 \mathrm{mM}$ glucose, $20 \mathrm{mM}$ Tris, $2.0 \mathrm{mM} \mathrm{NaH}_{2} \mathrm{HPO}_{4}$, pH 7.4.

Materials. Bovine serum albumin, rattlesnake venom
(Crotalus atrox), guanosine 5'-triphosphate (GTP), and cAMP were purchased from Sigma Chemical Co., St. Louis, Mo.; collagenase (type I, 125-250 U/mg) was purchased from Worthington Biochemical Corp., Freehold, N. J.; sodium heparin (Panheprin, 1,000 USP U/ml) from Abbott Laboratories, Chemical Div., North Chicago, Ill.; [ $\alpha-{ }^{32}$ P]ATP (25 $\mathrm{Ci} / \mathrm{mM}$ ) was purchased from ICN Nutritional Biochemicals, Cleveland, Ohio; $\left[{ }^{3} \mathrm{H}\right] \mathrm{cAMP}(30-50 \mathrm{Ci} / \mathrm{mM})$ from New England Nuclear, Boston, Mass. Synthetic 8-arginine-VP (385 U/mg) and MIX were purchased from CalbiochemBehring Corp., American Hoechst, San Diego, Calif.; RIA kits for the measurement of cAMP content, cholera toxin, and 5'-guanylimidodiphosphate $(\mathrm{Gpp}(\mathrm{NH}) \mathrm{p})$ were purchased from Schwartz/Mann Div., Becton, Dickinson \& Co., Orangeburg, N. Y. These and all other compounds and reagents were of the highest quality available from standard suppliers.

\section{RESULTS}

Adenylate cyclase. When expressed per tubular protein content, basal activities of adenylate cyclase in MCT and MAL were significantly lower in NDI mice than in controls (Fig. 1). The differences were less prominent when expressed per tubule length, and reached statistical significance between control and NDI mice only for MAL (Table II).

Adenylate cyclase in MAL and MCT was markedly stimulated by [8-arginine]-VP (AVP), as well as by nonhormonal agents $\mathrm{NaF}$ and $\mathrm{Gpp}(\mathrm{NH}) \mathrm{p}$ in both control and NDI mice. AVP stimulated adenylate cyclase in a dose-dependent manner; maximal stimulation was reached at a concentration of $\sim 1 \mu \mathrm{M}$ AVP in both tubular segments as well as in both control and NDI

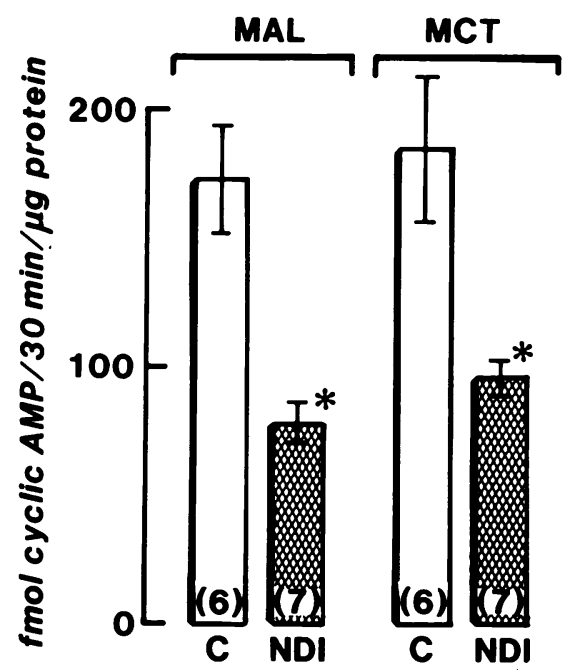

FIGURE 1 Basal adenylate cyclase activity in MCT and MAL in normal, control (C) mice and mice with NDI. Enzyme activity is expressed in femtomoles of cAMP per $30 \mathrm{~min}$ per microgram of protein. Each bar represents the mean $\pm S E M$; numbers in parentheses at bottom of bars indicate the number of animals; the value for each animal is the mean of four to six samples. $\square$, control mice; $\mathbb{Z}$, NDI mice; *, values significantly lower than corresponding values in control mice $(P<0.01$ or higher level of significance; $t$ test). 
TABLE II

Basal Adenylate Cyclase Activities in MCT and MAL from Normal (Control) Mice and Mice with NDI

\begin{tabular}{cccc}
\hline & Control mice & NDI mice & $P$ value \\
\hline MCT & $\begin{array}{c}18.9 \pm 2.2 \ddagger \\
(10)\end{array}$ & $\begin{array}{c}15.1 \pm 1.9 \\
(9)\end{array}$ & NS \\
MAL & $19.1 \pm 1.6$ & $9.4 \pm 0.7 \S$ & $<0.001$ \\
& $(10)$ & $(9)$ & \\
\hline
\end{tabular}

Enzyme activity is expressed in femtomoles cAMP per 30 min per millimeter tubule length.

* For significance of difference between control and NDI mice; $t$ test.

\$ Denotes mean $\pm \mathrm{SEM}$; number of experiments is indicated in parentheses; value in each experiment is based on mean from four to six samples.

$\$$ Significantly different from MCT value of NDI mice ( $P$ $<0.02 ; t$ test).

mice (Fig. 2). The half-maximal stimulation was achieved in all tubule segments at $\sim 10 \mathrm{nM}$ AVP in both control and NDI mice (Fig. 2).

When expressed per tubule length (Table III), the stimulation of adenylate cyclase by $1 \mu \mathrm{M}$ AVP in MCT was not significantly different between control and NDI mice, whether expressed in absolute (net increase) or relative (percent increase over basal value) terms (Table III). When expressed per tubular protein, however, the increase in adenylate cyclase activity in response to a maximal dose of AVP was slightly but significantly lower (by $\sim-24 \%$ ) in NDI mice than in controls; relative $(\% \Delta)$ stimulation by AVP was not dif- ferent between NDI and controls (Fig. 3, right panel). Lower activity of AVP-stimulated adenylate cyclase in MCT of NDI mice when expressed per tubule protein was apparent over the whole range of AVP concentrations tested (Fig. 2, right panel). Incubation with 10 $\mathrm{mM} \mathrm{NaF}$ stimulated adenylate cyclase in MCT of both control and NDI mice $>10$-fold (Table IV). The increase tended to be lower in NDI mice than in controls, but the difference was not statistically significant within a given number of experiments (Table IV). A similar pattern of $\mathrm{NaF}$-stimulated activities appeared when expressed per tubular protein (data not shown).

When assayed under the same conditions, the stimulation of adenylate cyclase by AVP was markedly lower $(>60 \%)$ in MAL of NDI mice compared with controls. This profound difference was highly significant, regardless of whether the results were expressed per tubular length (Table III) or per tubular protein (Fig. 3, left panel). The \% $\%$ AVP-induced increase in adenylate cyclase activity tended to be slightly lower in NDI mice than in controls; however, the difference was small and not statistically significant (Table III). The reduced stimulation of adenylate cyclase in MAL of NDI mice was apparent over a wide range of AVP concentrations (Fig. 2, left panel). Incubation with 10 $\mathrm{mM} \mathrm{NaF}$ (Table IV) increased adenylate cyclase $>20$ times in MAL of both control and NDI mice. This stimulation was, however, significantly lower in NDI than in controls, either when expressed per tubule length (Table IV) or per tubule protein (data not shown). The $\% \Delta$ increase of adenylate cyclase activity in response to $\mathrm{NaF}$ was not significantly different between control and NDI mice.

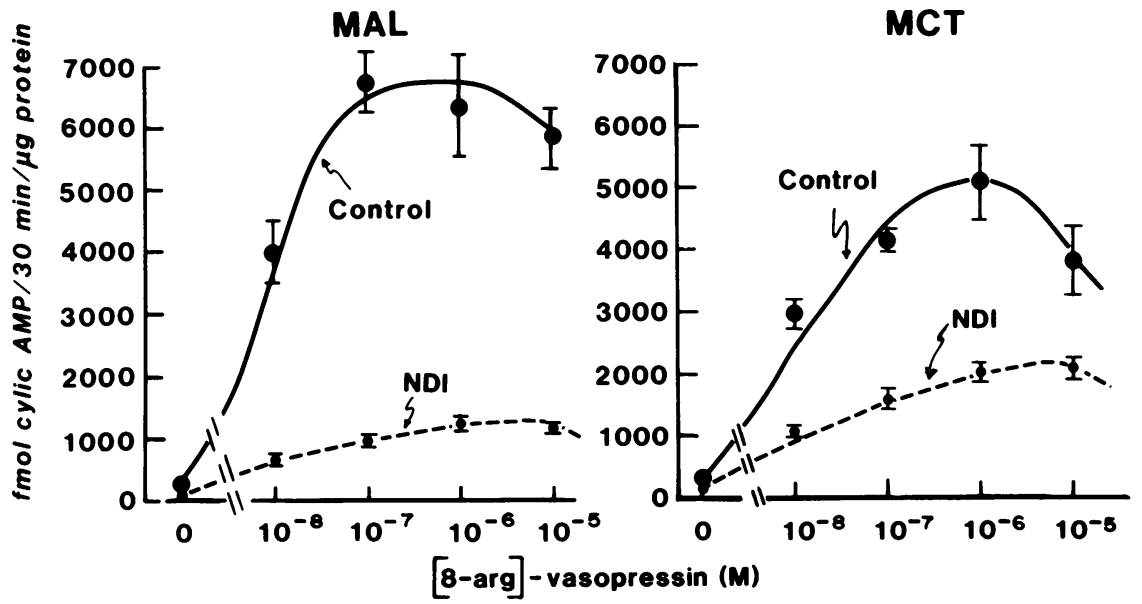

FIGURE 2 Adenylate cyclase activity in response to various concentrations of AVP in MCT (right panel) and in MAL (left panel) of normal (control) mice and mice with NDI. Enzyme activity is expressed in femtomoles of cAMP per 30 min per microgram of protein. Each point represents the mean \pm SEM of 6-10 samples. The difference in AVP-sensitive adenylate cyclase activity between control and NDI mice in this particular experiment was quantitatively more pronounced compared with the average differences (Table III, Fig. 3). _ , control mice; - - -, NDI mice. 
TABLE III

Effect of $1 \mu M$ AVP on Adenylate Cyclase Activity in MCT and in MAL from Normal (Control) Mice and Mice with NDI

\begin{tabular}{|c|c|c|c|c|c|c|c|c|}
\hline \multirow[b]{2}{*}{ Experiment } & \multicolumn{4}{|c|}{ Control mice } & \multicolumn{4}{|c|}{ NDI mice } \\
\hline & Basal & $1 \mu \mathrm{M} A V^{\prime} \mathrm{P}$ & $\Delta$ (AVP-basal) & $\% \Delta$ & Basal & $1 \mu \mathrm{M}$ AVP & $\Delta$ (AVP-basal) & $\% \Delta$ \\
\hline \multicolumn{9}{|l|}{ МCT } \\
\hline 1 & $9.1 \pm 0.9^{*}(5)$ & $244.9 \pm 15.9(6)$ & 235.8 & 2,591 & $12.5 \pm 0.7(6)$ & $242.5 \pm 29.7(6)$ & 230.0 & 1,840 \\
\hline 2 & $9.9 \pm 1.1 \quad(6)$ & $225.8 \pm 10.2(6)$ & 215.9 & 2,180 & $9.6 \pm 1.1(6)$ & $233.6 \pm 17.5(6)$ & 224.0 & 2,333 \\
\hline 3 & $16.4 \pm 1.2 \quad(6)$ & $237.0 \pm 19.1(5)$ & 220.6 & 1,345 & $12.2 \pm 1.1(5)$ & $292.4 \pm 22.0(6)$ & 280.2 & 2,296 \\
\hline 4 & $21.9 \pm 1.3$ & $247.0 \pm 6.3$ & 280.2 & 1,027 & $14.3 \pm 1.1(4)$ & $268.0 \pm 22.0$ & 253.7 & 1,774 \\
\hline Mean \pm SEM & $14.3 \pm 3.0$ & $238.6 \pm 4.8$ & $224.3 \pm 4.2 \ddagger$ & $1,786 \pm 362 \ddagger$ & $12.1 \pm 0.9$ & $259.1 \pm 13.2$ & $246.9 \pm 12.8 t$ & $2,061 \pm 147 t$ \\
\hline \multicolumn{9}{|l|}{ MAL } \\
\hline 1 & $10.7 \pm 1.4(6)$ & $434.2 \pm 29.1(6)$ & 432.5 & 3,957 & $8.6 \pm 0.7(5)$ & $188.9 \pm 20.0(6)$ & 180.3 & 2,096 \\
\hline 2 & $10.8 \pm 0.9(6)$ & $392.7 \pm 28.4(6)$ & 381.9 & 3,536 & $8.4 \pm 0.3(5)$ & $204.5 \pm 14.2(6)$ & 196.1 & 2,334 \\
\hline 3 & $19.1 \pm 1.1(6)$ & $331.4 \pm 15.4(6)$ & 312.0 & 1,635 & $8.9 \pm 0.6(6)$ & $204.7 \pm 9.2$ & 195.8 & 2,200 \\
\hline 4 & $24.9 \pm 3.7(4)$ & $421.8 \pm 5.1 \quad(4)$ & 396.9 & 1,593 & $7.2 \pm 1.1(4)$ & $148.9 \pm 12.4(5)$ & 141.7 & 1,968 \\
\hline Mean \pm SEM & $16.3 \pm 3.4$ & $395.0 \pm 22.9$ & $378.5 \pm 23.8 t$ & $2,680 \pm 621 t$ & $8.3 \pm 0.4$ & $186.7 \pm 13.1 \S$ & $178.4 \pm 12.81 \S$ & 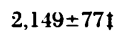 \\
\hline
\end{tabular}

Enzyme activity is expressed in femtomoles cAMP per 30 min per millimeter tubule length.

* Denotes mean $\pm S E M$; number of samples is indicated in parentheses.

† Denotes significant increase $(P<0.025$ or higher level of significance; paired $t$ test).

Denotes values significantly different from corresponding value in control mice $(P<0.01, t$ test).

The effects of $\mathrm{Gpp}(\mathrm{NH}) \mathrm{p}$ on adenylate cyclase were also explored in both MCT and MAL, and the pattern of responses in NDI and control mice was similar to that for NaF and AVP. In both MCT and in MAL, 0.1 $\mathrm{mM}$ Gpp(NH)p stimulated adenylate cyclase more than 10 times in both types of animal (data not shown). In MAL, adenylate cyclase activity stimulated by $\mathrm{Gpp}(\mathrm{NH}) \mathrm{p}$ was markedly lower in NDI mice than in controls; for MCT, the net increase was slightly lower in NDI than controls, but the \% $\%$ increase was similar. The pattern of findings was similar when expressed per tubular length or per tubular protein.

It was recently reported (33) that adenylate cyclase activity in the renal cortex had a higher dependency on GTP in the kidney of a pseudohypoparathyroid patient than in a normal kidney (33); therefore, we explored whether this factor might account for differences in adenylate cyclase activities in tubules of NDI and control mice. Addition of $10 \mu \mathrm{M}$ GTP had no effect on either basal or AVP-stimulated adenylate cyclase in MCT or MAL of either control or NDI mice (data not shown).

cAMP-PDIE. In control (normal) mice the activity of cAMP-PDIE was not significantly different between MCT and MAL (Table V); nor was the cAMP-PDIE activity in MAL of NDI mice significantly different from the activity in MAL of control mice (Table V, Fig. 4, left panel). On the other hand, cAMP-PDIE activity in MCT was markedly higher in NDI mice than in MCT of controls (Table V, Fig. 4, right panel). This difference in cAMP-PDIE activity was highly significant regardless of whether it was expressed per

TABLE IV

Effect of $10 \mathrm{mM} \mathrm{NaF}$ on Adenylate Cyclase Activity in MCT and MAL from Normal (Control) Mice and Mice with NDI

\begin{tabular}{|c|c|c|c|c|c|c|c|c|}
\hline \multirow[b]{2}{*}{ Experiment } & \multicolumn{4}{|c|}{ Control mice } & \multicolumn{4}{|c|}{ NDI mice } \\
\hline & Basal & $10 \mathrm{mM} \mathrm{NaF}$ & $\Delta(\mathrm{NaF}$-basal $)$ & $\% \Delta$ & Basal & $10 \mathrm{mM} \mathrm{NaF}$ & $\Delta(\mathrm{NaF}$-basal $)$ & $\% \Delta$ \\
\hline \multicolumn{9}{|l|}{ MCT } \\
\hline 1 & $17.3 \pm 1.3^{*}(5)$ & $170.5 \pm 10.6(4)$ & 153.2 & 885 & $12.4 \pm 1.0(5)$ & $153.9 \pm 6.5(5)$ & 141.5 & 1,141 \\
\hline 2 & $21.9 \pm 1.3$ & $298.4 \pm 30.7(5)$ & 276.5 & 1,262 & $14.3 \pm 1.1(4)$ & $185.8 \pm 12.8(4)$ & 171.5 & 1,199 \\
\hline 3 & $25.3 \pm 3.1$ & $351.2 \pm 24.2(5)$ & 325.9 & 1,288 & $16.1 \pm 4.1(5)$ & $265.9 \pm 26.1(5)$ & 249.8 & 1,551 \\
\hline Mean \pm SEM & $21.5 \pm 2.3$ & $273.3 \pm 53.6$ & $251.9 \pm 51.3 \ddagger$ & $1,145 \pm 130 t$ & $14.3 \pm 1.1$ & $201.9 \pm 33.3$ & $187.6 \pm 32.3 t$ & $1,297 \pm 128 t$ \\
\hline \multicolumn{9}{|l|}{ MAL } \\
\hline 1 & $18.1 \pm 3.3(4)$ & $486.4 \pm 22.5$ & 468.3 & 2,587 & $8.2 \pm 0.8(5)$ & $275.9 \pm 20.6(5)$ & 267.7 & 3,264 \\
\hline 2 & $24.9 \pm 3.7(4)$ & $634.6 \pm 26.7(4)$ & 609.7 & 2,448 & $7.2 \pm 1.1(4)$ & $249.4 \pm 19.1(4)$ & 242.2 & 3,363 \\
\hline 3 & $20.7 \pm 4.6(5)$ & $691.3 \pm 39.7(5)$ & 670.6 & 3,239 & $14.8 \pm 1.4(5)$ & $352.9 \pm 40.2(4)$ & 338.1 & 2,284 \\
\hline Mean \pm SEM & $21.2 \pm 1.9$ & $604.1 \pm 61.0$ & $582.8 \pm 59.9 !$ & $2,758 \pm 243 t$ & $10.1 \pm 2.4$ & $292.7 \pm 31.0 \$$ & $282.6 \pm 28.7 \hbar \S$ & $2,971 \pm 344 t$ \\
\hline
\end{tabular}

Enzyme activity is expressed in femtomoles cAMP per $30 \mathrm{~min}$ per millimeter tubular length.

* Denotes mean \pm SEM; number of samples is indicated in parentheses.

t Denotes significant increase ( $P<0.05$ or higher level of significance; paired $t$ test).

$\$$ Denotes values significantly different from corresponding value in control mice $(P<0.02 ; t$ test). 


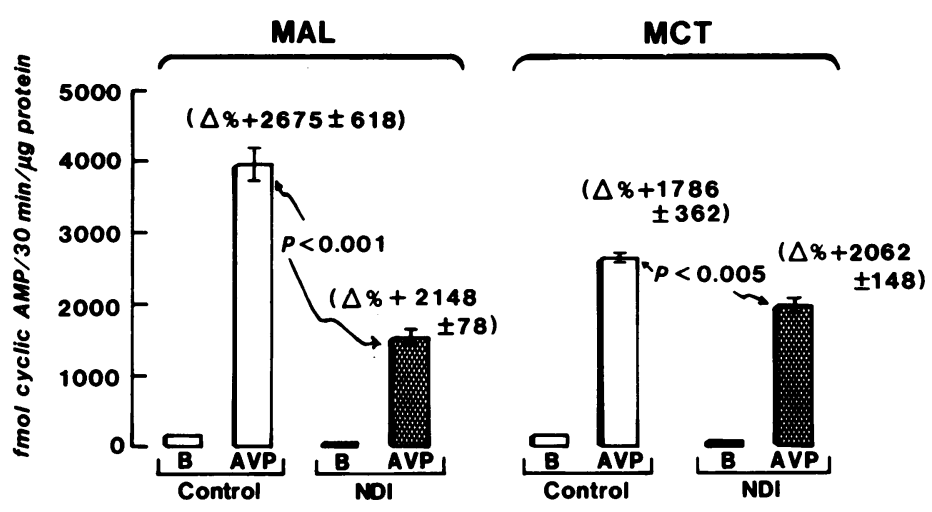

FIGURE 3 Stimulation of adenylate cyclase activity by AVP in MCT (right panel) and MAL (left panel) of normal (control) mice and mice with NDI. Enzyme activity is expressed in femtomoles of cAMP per 30 min per microgram of protein. B, basal activity; AVP, activity in the presence of $1 \mu \mathrm{M}$ AVP. Each bar represents mean \pm SEM from four animals; the value for each animal is the mean of four to six samples. $\square$, control mice; $\mathbb{Z}$, NDI mice. AVP-stimulated adenylate cyclase in MAL of control mice is significantly higher $(P<0.005 ; t$ test $)$ than in MCT of control mice. AVPstimulated adenylate cyclase activity in MCT of NDI mice is significantly higher $(P<0.05 ; t$ test $)$ than in MAL of NDI mice. AVP-stimulated adenylate cyclase activities of both MAL and MCT of control mice are significantly higher $(P<0.005$, or higher degree of significance; $t$ test $)$ than in the corresponding segments in NDI mice.

tubule length (Table V) or per tubule protein (Fig. 4 , right panel).

Accumulation of cAMP in intact MCT and in MAL. To determine how the differences in adenylate cyclase and cAMP-PDIE between control and NDI mice described above are reflected in cAMP levels in tubular epithelial cells, cAMP accumulation (basal and in response to AVP or other agents) was examined in freshly isolated intact tubules. Tubule segments were incubated in a medium either with or without AVP (and other agents) as described in detail in Methods.

When MCT segments from control mice were incubated in the absence of a cAMP-PDIE inhibitor, the addition of $1 \mu \mathrm{M}$ AVP elicited a striking ( 10 times) increase in cAMP accumulation (Table VI, Fig. 5, left panel). No such increase in response to AVP, however, was seen in MCT of NDI mice (Table VI, Fig. 5, left panel).

Because we observed a higher activity of cAMPPDIE in MCT of NDI mice than of control mice (Table V, Fig. 4), we further assessed the effect of cAMPPDIE inhibition on cAMP accumulation in the presence or absence of AVP. Incubation of control MCT in a medium containing $0.5 \mathrm{mM}$ 1-methyl-3-isobutylxanthine $(\mathrm{MIX})^{2}$ resulted in markedly higher cAMP levels compared with basal levels without MIX

\footnotetext{
${ }^{2}$ In a preliminary experiment, $0.5 \mathrm{mM}$ MIX inhibited cAMP-PDIE activity to a similar extent $(\sim 80 \%)$ in MAL and MCT of both control and NDI mice.
}

TABLE V

Activity of cAMP-PDIE in MCT and MAL from Normal (Control) Mice and Mice with NDI

\begin{tabular}{|c|c|c|c|c|}
\hline \multirow[b]{2}{*}{ Experiment } & \multicolumn{2}{|c|}{ MCT } & \multicolumn{2}{|c|}{ MAL } \\
\hline & Control & NDI & Control & NDI \\
\hline 1 & $14.7 \pm 0.9 *(12)$ & $26.3 \pm 1.4(11)$ & $16.4 \pm 1.1(12)$ & $16.0 \pm 1.0(12)$ \\
\hline 2 & $7.8 \pm 0.4 \quad(12)$ & $24.8 \pm 1.8(12)$ & $10.4 \pm 0.5(11)$ & $15.4 \pm 1.4(12)$ \\
\hline 3 & $13.2 \pm 1.9$ & $29.1 \pm 0.7(6)$ & $17.2 \pm 0.9(5)$ & $20.2 \pm 1.7(6)$ \\
\hline 4 & $5.7 \pm 0.4$ & $36.2 \pm 2.4(6)$ & $5.7 \pm 0.9(6)$ & $22.2 \pm 1.6(6)$ \\
\hline 5 & $18.8 \pm 1.1$ & $32.3 \pm 5.8(4)$ & $25.5 \pm 0.8(4)$ & $24.6 \pm 4.3(4)$ \\
\hline Mean \pm SEM & $12.0 \pm 2.4$ & $29.7 \pm 2.17$ & $15.0 \pm 3.3 \S$ & $19.7 \pm 1.8^{\prime \prime}$ \\
\hline
\end{tabular}

Enzyme activity is expressed in femtomoles cAMP per min per millimeter tubule length.

* Denotes mean \pm SEM; number of samples is indicated in parentheses.

‡ Significantly different from the control MCT $(P<0.01$, paired $t$ test; $P<0.001$, group $t$ test $)$.

$\$$ Not significantly different from the control MCT.

"Significantly different from MCT of NDI mice $(P<0.001$, paired $t$ test; $P<0.01$, group $t$ test). 


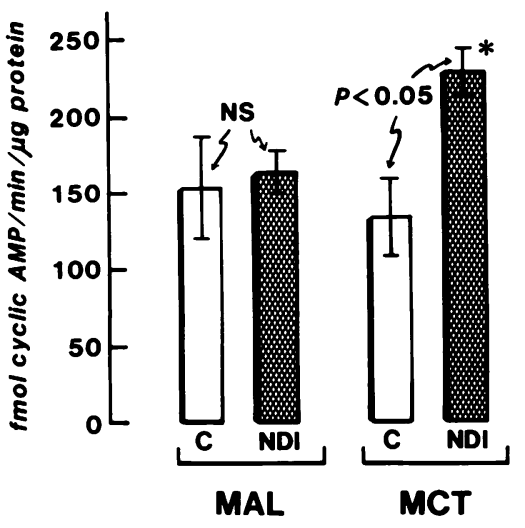

FIGURE 4 Activity of cAMP-PDIE in MCT (right panel) and MAL (left panel) in normal (control) mice and mice with nephrogenic diabetes insipidus NDI. Enzyme activity is expressed in femtomoles of cAMP per min per microgram of protein. Each column represents the mean $\pm S E M$ from five animals; the value for each animal is the mean of at least four to six samples. $\square$, control mice; $\mathbb{Z}$, NDI mice; $*$ Value significantly higher $(P<0.05 ; t$ test $)$ than in control mice, as well as higher than the value in MAL of NDI mice. Values for control MCT and control MAL were not significantly different from each other.

(Table VI, Fig. 5, right panel). Addition of $1 \mu \mathrm{M}$ AVP in the presence of MIX resulted in an increase in cAMP level that was much greater than the cAMP level observed in response to AVP or MIX alone (Table VI, Fig. 5, right panel). In the absence of MIX, the basal
cAMP levels in MCT from NDI mice were slightly but significantly lower than in MCT of controls, when expressed per tubular protein (Fig. 5).

The most striking difference between control and NDI mice was the complete failure of AVP to increase cAMP in MCT of NDI mice, in contrast to the striking stimulatory effect of AVP in MCT of control mice (Table VI, Fig. 5, left panel). Addition of MIX alone caused a significant increase in the basal cAMP level in MCT of NDI mice; even more importantly, addition of AVP in the presence of MIX increased cAMP in MCT of NDI mice more than three times over the basal level without MIX (Table VI, Fig. 5, right panel). In the presence of MIX, the relative cAMP increase in response to AVP in MCT from NDI mice (3.3 times) was similar to the 3.8-fold increase by AVP in MCT of control mice (Fig. 5, right panel). Under all conditions tested, the cAMP content (picomoles cAMP/microgram protein) in MCT of NDI mice was significantly lower compared, under corresponding conditions, with MCT of control mice (Fig. 5).

To learn whether cAMP levels in MCT of NDI mice could be elevated in response to nonhormonal stimuli of adenylate cyclase, the effect of choleratoxin, a known agonist of adenylate cyclase (34), was briefly tested. Tubules were incubated with $1 \mu \mathrm{g} / \mathrm{ml}$ cholera toxin under the same conditions as described in Methods except that the incubation time was 60 min instead of $20 \mathrm{~min}$, as used in all other experiments. The pattern of responses to cholera toxin was similar to that seen

TABLE VI

Effect of Incubation with $1 \mu M$ AVP and/or with $0.5 \mathrm{mM}$ MIX on cAMP Accumulation in MCT and MAL from Normal (Control) Mice and Mice with NDI

\begin{tabular}{|c|c|c|c|c|c|c|c|c|}
\hline \multirow[b]{2}{*}{ Experiment } & \multicolumn{4}{|c|}{ Control mice } & \multicolumn{4}{|c|}{ NDI mice } \\
\hline & Basal & AVP & MIX & MIX + AVP & Basal & AVP & MIX & MIX + AVP \\
\hline \multicolumn{9}{|l|}{ MCT } \\
\hline 1 & $3.0 \pm 0.1(2)^{*}$ & $77.5 \pm 43.9(3)$ & $4.9 \pm 0.7$ & $219.9 \pm 92.6(3)$ & $4.4 \pm 0.1(2)$ & $3.9 \pm 0.4(3)$ & $19.1 \pm 9.8(3)$ & $55.6 \pm 7.2(3)$ \\
\hline 2 & $1.6 \pm 0.2(3)$ & $71.7 \pm 15.2(3)$ & $11.1 \pm 6.8$ & $26.2 \pm 8.8$ & $2.6 \pm 0.6(3)$ & $3.8 \pm 0.4(3)$ & $11.1 \pm 3.4(3)$ & $22.9 \pm 2.5(3)$ \\
\hline 3 & $13.6 \pm 3.6(3)$ & $136.7 \pm 29.9(2)$ & $68.2 \pm 16.9(3)$ & $146.6 \pm 13.1(3)$ & $7.9 \pm 1.1(3)$ & $8.5 \pm 1.0(3)$ & $12.8 \pm 0.6(3)$ & $22.8 \pm 6.2(3)$ \\
\hline 4 & $9.2 \pm 1.9(3)$ & $69.7 \pm 24.0$ & $114.7 \pm 37.3(3)$ & $209.9 \pm 60.5(3)$ & $2.5 \pm 1.0(3)$ & $2.8 \pm 0.9(3)$ & $6.7 \pm 1.3(3)$ & $42.7 \pm 4.9(3)$ \\
\hline 5 & $4.5 \pm 0.4(3)$ & $111.4 \pm 27.8$ & $24.1 \pm 4.3$ & $254.2 \pm 7.7$ & $2.3 \pm 0.6(3)$ & $4.4 \pm 1.8$ & $7.8 \pm 1.1(3)$ & $46.2 \pm 1.5(3)$ \\
\hline Mean \pm SEM & $6.6 \pm 1.4$ & $90.3 \pm 13.1 \rrbracket$ & $44.6 \pm 13.1 \ddagger$ & $171.4 \pm 28.6 \pm \S$ & $3.9 \pm 0.7$ & $4.6 \pm 0.6$ & $11.5 \pm 2.1 t$ & $38.0 \pm 3.9 t \S$ \\
\hline$n^{\prime \prime}$ & 14 & 14 & 15 & 15 & 14 & 15 & 15 & 15 \\
\hline \multicolumn{9}{|l|}{ MAL } \\
\hline 1 & $2.8 \pm 0.9(4)$ & $3.5 \pm 0.5(6)$ & $3.5 \pm 0.5(2)$ & $2.9 \pm 0.9(3)$ & $2.4 \pm 0.3(3)$ & $3.3 \pm 1.0(3)$ & $3.2 \pm 0.7(3)$ & $16.3 \pm 7.6(3)$ \\
\hline 2 & $1.8 \pm 0.1(2)$ & $2.6 \pm 1.2(3)$ & $2.0 \pm 0.4(3)$ & $2.9 \pm 1.0(3)$ & $4.7 \pm 0.5(3)$ & $7.4 \pm 0.6(3)$ & $6.2 \pm 0.9(3)$ & $6.1 \pm 0.4(3)$ \\
\hline 3 & $7.2 \pm 2.3(2)$ & $6.3 \pm 0.8(3)$ & $6.2 \pm 3.2(3)$ & $13.1 \pm 5.4(3)$ & $7.9 \pm 1.0(3)$ & $6.8 \pm 1.3(3)$ & $5.8 \pm 0.6(3)$ & $7.1 \pm 0.1(3)$ \\
\hline 4 & $5.0 \pm 1.4(3)$ & $5.3 \pm 1.0(2)$ & $12.3 \pm 1.9(3)$ & $14.3 \pm 1.5(3)$ & $7.2 \pm 0.4(3)$ & $7.3 \pm 0.9(3)$ & $7.0 \pm 1.2(3)$ & $7.4 \pm 1.5(3)$ \\
\hline 5 & $3.7 \pm 0.5(3)$ & $3.9 \pm 0.8(3)$ & $3.7 \pm 0.4(3)$ & $6.7 \pm 0.9$ & $7.1 \pm 0.8$ & $7.4 \pm 1.5(3)$ & $7.6 \pm 1.2(3)$ & $7.8 \pm 0.5(3)$ \\
\hline Mean \pm SEM & $3.9 \pm 0.6$ & $4.1 \pm 0.4$ & $5.7 \pm 1.2$ & $7.6 \pm 1.5$ & $5.9 \pm 0.6$ & $6.5 \pm 0.6$ & $5.9 \pm 0.5$ & $8.9 \pm 1.6$ \\
\hline$n$ & 14 & 17 & 14 & 15 & 15 & 15 & 15 & 15 \\
\hline
\end{tabular}

All values are expressed in femtomoles cAMP per millimeter tubule length (for details see Methods).

* Denotes mean $\pm S E M$; number of samples is indicated in parentheses.

t Denotes value significantly different $(P<0.01$ or higher level of significance; $t$ test) from basal.

$\$$ Denotes value significantly different from MIX alone or AVP alone ( $\mathrm{P}<0.02$ or higher level of significance; $t$ test).

" $n$, total number of samples. 

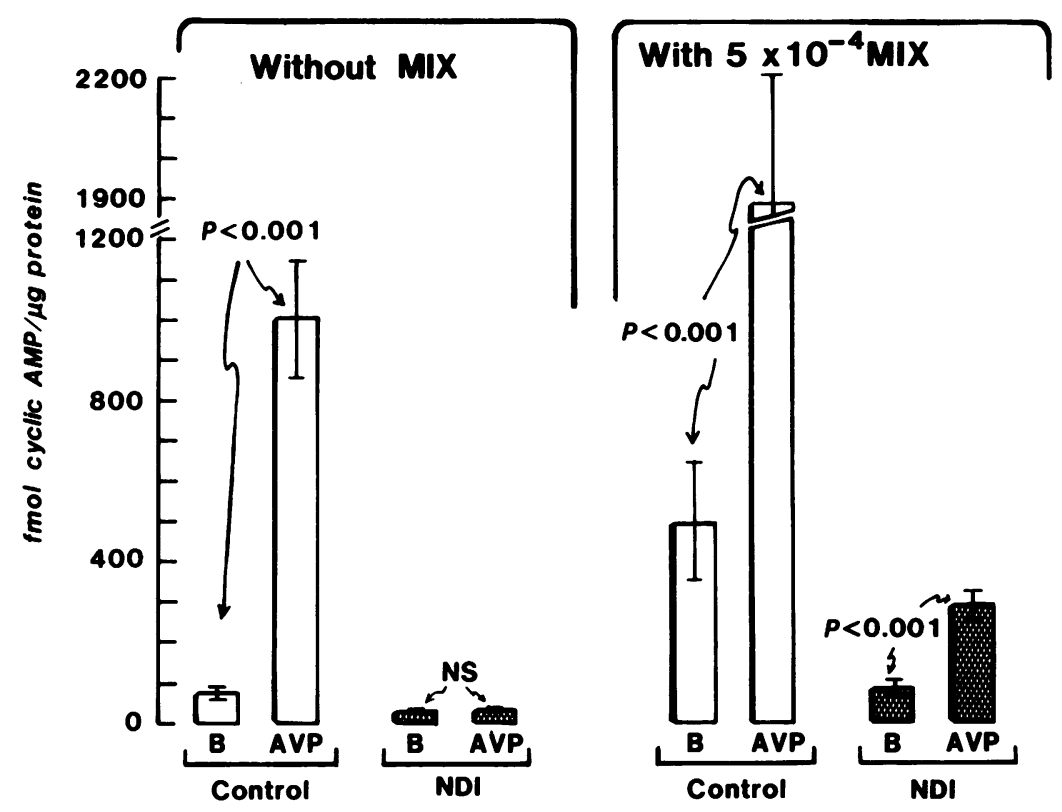

Figure 5 Effect of $1 \mu \mathrm{M} \mathrm{AVP}$ and of $0.5 \mathrm{mM}$ MIX on the cAMP content (expressed in femtomoles of cAMP per microgram of protein) of MCT in normal (control) mice and mice with NDI. $B$, basal value; AVP, content in the presence of $1 \mu \mathrm{M}$ AVP. Each bar represents the mean \pm SEM of 14-15 samples dissected from five control and five NDI mice. $\square$, control mice; $\square$, NDI mice. Left panel: incubations in the absence of MIX; right panel: incubations in the presence of $0.5 \mathrm{mM}$ MIX. The basal cAMP level in MCT of NDI mice was significantly lower $(P<0.02$; $t$ test) than in MCT of control mice. Levels of cAMP in MCT of either control or NDI mice in the presence of MIX (right panel) were always significantly $(P<0.01 ; t$ test) higher than corresponding values of MCT incubated in the absence of MIX (left panel).

with AVP. In preliminary experiments, we observed that incubation of MCT from control mice with cholera toxin alone caused a marked accumulation of cAMP, similar to that achieved with AVP (data not shown). When incubated in the presence of MIX, cholera toxin induced about the same cAMP accumulation as AVP and MIX in control MCT (Table VII). In MCT of NDI mice, cholera toxin plus MIX also increased levels of cAMP to about the same extent as AVP plus MIX; however, as with AVP, the levels of cAMP that ac- cumulated in MCT of NDI mice in response to cholera toxin alone were much lower than in MCT of control mice (Table VII).

Basal cAMP levels were not different between MAL of NDI mice and controls (Table VI). Levels of cAMP in MAL of either control or NDI mice did not change in response to AVP whether or not MIX was present (Table VI). The pattern of results was the same when expressed per micogram of tubular protein. Similarly, incubation with cholera toxin had no effect on cAMP

TABLE VII

Effects of Incubation with $1 \mu M A V P$ and $1 \mu \mathrm{g} / m$ l Cholera Toxin (CT) in the Presence of $0.5 \mathrm{mM}$ MIX on cAMP Accumulation in MCT of Normal (Control) Mice and Mice with NDI

\begin{tabular}{llrr}
\hline & MIX & MIX + AVP & \multicolumn{1}{c}{ MIX + CT } \\
\hline Control & $91.4 \pm 21.1^{*}(6)$ & $178.3 \pm 31.1 \ddagger(6)$ & $160.8 \pm 30.4(6)$ \\
NDI & $11.9 \pm 1.6 \S(6)$ & $22.8 \pm 2.9 \ddagger \S(6)$ & $28.3 \pm 8.6 \S(6)$ \\
\hline
\end{tabular}

cAMP levels are expressed in femtomoles per millimeter tubule length.

* Denotes mean $\pm S E M$; numbers in parentheses indicate the number of samples. I Significantly higher $(P<0.05$ or less; $t$ test $)$ than cAMP level with MIX alone. $\$$ Significantly lower $(P<0.005$ or less; $t$ test $)$ than corresponding control value from control mice. 
levels in MAL of either control or NDI mice (data not shown).

\section{DISCUSSION}

Results from our previous study (4) suggested that the renal concentrating defect in mice with hereditary NDI is associated with an abnormal VP-dependent metabolism of cAMP. Further analysis of this defect in specific segments of the nephron was necessary, for a number of reasons.

As shown by Chabardes et al. (15) and confirmed in the present experiments, VP-sensitive adenylate cyclase in the mouse kidney is present not only in collecting tubules but also in the ascending limb of Henle's loop. In rat outer medulla, MAL outnumber MCT by a factor of about 5:1 $(20,35)$. According to our present observations, because a similar or even higher ratio holds for the outer medulla of the mouse kidney, it is likely that most of the adenylate cyclase activity measured in homogenates prepared from mouse medulla represents predominantly adenylate cyclase from the ascending limbs of Henle's loops, whereas only a small proportion is derived from the collecting tubules. Although the VP-sensitive cAMP system in the MAL may contribute to dilution of tubular fluid in this segment $(17,18)$ and increase medullary osmolarity (36), the basic role of VP required for formation of hypertonic urine (the control of water permeability through cAMP as a "second messenger") (37) has been found (6) and confirmed $(7,31,38)$ only in collecting tubules (37). Moreover, although a highly active VP-sensitive adenylate cyclase has been found in the collecting tubules of all mammalian species examined to date (16), the VP-sensitive adenylate cyclase in the MAL, in contrast, appears to be less active in some species than in others (16) and, to date, has not been detected in the human kidney $(16,39)$. These considerations suggest that a concentrating defect such as in NDI mice can only be identified by separately examining the VP-sensitive cAMP system in collecting tubules and in the ascending limbs of Henle's loops.

The major observation in the present experiments is the striking difference in cAMP levels in MCT accumulated in response to AVP. The complete lack of cAMP response to AVP in MCT from NDI mice (especially when compared with the more than 10fold increase in MCT of control mice), strongly suggests that this is the primary defect and cellular basis for the unresponsiveness of NDI mice to AVP in vivo (1, 3, 4, 10). Even if additional defect(s) in the cellular action of VP in steps (known or putative) subsequent to cAMP accumulation (5) should be uncovered in future studies, the complete absence of a cAMP increase in response to AVP in MCT (Fig. 5, Table VI) in itself can explain the functional unresponsiveness to the hormone.
Unresponsiveness of MCT from NDI mice to AVP is apparently the result of a combination of several factors; higher cAMP-PDIE activity and lower adenylate cyclase. Lower activity of AVP-sensitive adenylate cyclase could be observed in MCT of NDI mice only when expressed per unit protein (Fig. 3, right panel), but not when related to tubular length (Table III). Moreover, adenylate cyclase in MCT of NDI mice did not differ from MCT of control mice in relative sensitivity (\% $\%$ increase over basal) to AVP, $\mathrm{NaF}$, or $\mathrm{Gpp}(\mathrm{NH}) \mathrm{p}$; the absolute (net) increase of adenylate cyclase in response to $\mathrm{NaF}$ or $\mathrm{Gpp}(\mathrm{NH}) \mathrm{p}$ was lower, although not statistically significant, in MCT of NDI compared with control mice. The concentration of AVP required for half-maximal stimulation of adenylate cyclase, which likely reflects affinity for AVP (40), does not appreciably differ between NDI and control mice (Fig. 2). An abnormally high requirement of adenylate cyclase for GTP (33) seems to be ruled out. These features would suggest a defect in the catalytic subunit of adenylate cyclase, which is not specifically related to AVP effect. Although such a partial alteration in the properties of adenylate cyclase might contribute to the lower basal level of cAMP in MCT of NDI mice, it cannot explain the total inability of AVP to increase cAMP levels (Fig. 5, Table VI).

Higher cAMP-PDIE activity in MCT of NDI mice is likely to be a major factor in the unresponsiveness to VP. This is emphasized by the observation that MIX not only increased basal cAMP levels, but also restored the responsiveness of MCT to VP (Fig. 5). This higher specific activity of cAMP-PDIE suggests that cAMP is catabolized in MCT of NDI mice at a higher rate than in control animals. However, conditions for cAMP breakdown in situ almost certainly differ from those observed in vitro; hence, the actual quantitative differences in cAMP catabolism may be even more prominent in intact cells.

These findings suggest that an abnormally high rate of cAMP breakdown in MCT of NDI mice prevents increases in cAMP even after stimulation with high doses of AVP. Although treatment with MIX restored the \% responsiveness of MCT to AVP to approximately the same degree as that seen in MCT of control mice in the presence of MIX (about three-fold increase; Fig. 5, right panel), the absolute amount of cAMP accumulated in MCT from NDI mice is substantially lower than in MCT from control mice. The observations that accumulation of cAMP in response to MIX alone (Table VI, Fig. 5) or to cholera toxin (Table VII) are also much lower in MCT of NDI mice indicates that the observed defect does not only relate to the cAMP pool that is controlled by AVP. In addition to lower adenylate cyclase activity and higher cAMPPDIE activity in MCT of NDI mice, other factors could possibly play additional roles. For example, in intact 
MCT of NDI mice, the intracellular pool of ATP serving as substrate for cAMP generation may be abnormally low, and/or some co-factors of the adenylate cyclase system such as GTP, magnesium, or others, may be depleted.

The major abnormality found in MAL of NDI mice is a markedly lower activity of adenylate cyclase. Although this deficiency is much more pronounced than that observed in MCT, the major features are similar because the adenylate cyclase activity is low in MAL of NDI mice, both under basal conditions or after maximal stimulation with AVP (Table III, Fig. 3, left panel), $\mathrm{NaF}$ (Table IV), or $\mathrm{Gpp}(\mathrm{NH}) \mathrm{p}$. As for the MCT, the affinity of the AVP receptor is not diminished in the MAL of NDI mice. The inability to restore VP-sensitive adenylate cyclase activity in MAL of NDI mice to normal by addition of GTP also argues against the possibility that the abnormality lies in the guanyl nucleotide site (33).

When dissected from the same animal as MCT and tested under exactly the same conditions, the MAL from either control or NDI animals did not respond to AVP, MIX, or to cholera toxin (data not shown) by a change in cAMP levels. This total unresponsiveness is not the result of the absence of VP-sensitive adenylate cyclase (Table III, Fig. 3) to excessively high cAMP-PDIE (Table V, Fig. 4) or the resistance of cAMP-PDIE to MIX. ${ }^{2}$ Using the same preparative and assay conditions, we found consistent increases of cAMP in response to AVP in MAL dissected from the rat medulla $(13,41)$. This would suggest that the unresponsiveness in the MAL of mice may be the result of some as yet unknown feature that is peculiar to mouse MAL. Because the sensitivity of MAL adenylate cyclase to VP is well preserved, it does not appear probable that damage to the cell surface in MAL is a major factor in the VP unresponsiveness. It seems more likely that the mouse MAL may be vulnerable to depletion of some important co-factor(s) necessary for in situ cAMP formation, which might result from microdissecting and testing procedures that we currently employ. For example, ATP and/or GTP could be depleted during preparation. According to a recent report, ATPase activity in MAL is much higher than in MCT (42); this feature could make MAL more prone to depletion of nucleoside-5'-triphosphates.

The question may arise whether the observed alterations of the VP-sensitive cAMP system, in MCT, may be the consequence of polyuria rather than a primary, causative factor. Several observations argue against such a possibility. We previously observed that in rats with polyuria induced by potassium depletion, VPinduced cAMP accumulation in MCT is normal (or even higher) than in controls (41). Likewise, in polyuria induced by administration of lithium, the activities of basal and VP-stimulated adenylate cyclase or of
cAMP-PDIE in MCT and MAL were not different from controls (43). In MCT from normal (control) mice in which polyuria was induced by drinking $5 \%$ glucose, VP readily elicited an increase in cAMP. ${ }^{3}$ These observations in polyuric states of diverse etiology argue strongly against the possibility that abnormalities of cAMP metabolism in NDI mice are secondary to polyuria.

Comparison of present findings with our previous study (4) should be briefly considered. It should be realized that in the past study (4) the preparations were from whole medulla and papilla taken together, whereas the present study was localized to MCT and MAL, and also that enzyme assays differed at certain points.

Because MAL is numerically the predominant VPsensitive tubular segment in the medulla $(20,35)$, it is likely that lower VP-stimulated adenylate cyclase activity in preparations from the whole medulla (4) reflected the lower activity of adenylate cyclase in MAL (Table III, Fig. 3). As in the previous study (4), the apparent affinity of adenylate cyclase for VP (Fig. 2 ) is not altered in NDI mice. In the preceeding study, we found no difference in basal and $\mathrm{NaF}$-stimulated activity while these activities were lower in MCT and MAL of NDI mice (Fig. 1, Table IV). It should be realized that adenylate cyclase (basal or nonspecifically stimulated by $\mathrm{NaF}$ ) is a ubiquitous enzyme present in all cell types, whereas VP-sensitive adenylate cyclase in mouse renal medulla is limited to MAL and MCT $(15,16)$. Thus, the basal activity and $\mathrm{NaF}$ stimulated activity derived from MAL and MCT were admixed in whole medulla preparations with membranes from all other cell types, preventing detection of significant differences.

The abnormally high activity of cAMP-PDIE of NDI mice (Fig. 4, Table $\mathrm{V}$ ) probably went undetected in the past study for two reasons. First, the difference in CAMP-PDIE activity is limited to MCT and this nephron segment contributes little to total cell mass (35) in medulla. Second, in preparations from the whole medulla, cAMP-PDIE was assayed only in the cytosol (4) and at a substrate concentration of $0.5 \mathrm{mM}$ cAMP, which likely reflects mainly low-affinity, high $K_{\mathrm{m}}$ cAMP-PDIE (44). In the present studies on isolated tubules, 1 m.M cAMP substrate was used to pre-

\footnotetext{
${ }^{3}$ Polyuria was induced in control mice by allowing them to drink $5 \%$ glucose instead of tap water for 6-10 d (4). Urinary output increased from $0.85 \pm 0.2$ to $15.0 \pm 1.9(\mathrm{ml} / 24 \mathrm{~h}$; mean $\pm \mathrm{SE}$ ) and urine osmolality decreased from $3,556 \pm 97$ to $436 \pm 83\left(\mathrm{mosmol} / \mathrm{kg} \mathrm{H} \mathrm{H}_{2} \mathrm{O}\right.$; mean $\pm \mathrm{SE}$ ). In MCT microdissected from polyuric mice $1 \mu M$ AVP elicited a cA.MP increase analogous to that in control mice (Table VI). Basal level was: $5.5 \pm 1.5$ (fmol cAMP/mm); and with AVP significantly $(P<0.001, t$ test) higher: $90.1 \pm 11.9$ (fmol (A.MP/mm).
} 
dominantly detect the high-affinity, low- $K_{\mathrm{m}}$ variety of cAMP-PDIE $(23,44)$. Present results are, therefore, not only quite compatible with the previous study (4), but also emphasize the need for analysis of specific nephron segments to exactly localize the abnormalities in VP action.

The present observations not only provide new insights into the pathogenesis of hereditary NDI in mice, but also illustrate the importance of studying all aspects of cAMP metabolism in specific nephron segments separately. The results also stress the importance of cAMP-PDIE in the cellular dynamics of cAMP. Thus, even when no difference in VP-sensitive adenylate cyclase (expressed per tubule length) could be detected, nevertheless, a complete unresponsiveness of MCT to AVP (assessed as cAMP accumulation) may occur.

In conclusion, the results of the present study suggest that the lack of an antidiuretic response to VP in NDI mice in vivo may be the result of impaired VPsensitive cAMP metabolism in collecting tubules, specifically an inability to increase cAMP levels in response to AVP. This inability results perhaps partly from lower stimulation of MCT adenylate cyclase by AVP, but mainly from abnormally high cAMP-PDIE activity in MCT of NDI mice. A defect of adenylate cyclase in MAL may also conceivably contribute to the urinary concentrating defect in this experimental model of NDI by decreasing the buildup of interstitial gradient of solutes.

\section{ACKNOWLEDGMENTS}

The expert technical assistance of Mrs. Denise M. Heublein, Ms. Julie Braun, Mr. Thomas Haugen, and Mrs. Ethel Garrity, as well as the excellent secretarial help of Mrs. Ardith Walker and Ms. Bonnie Becker are gratefully acknowledged.

This work was supported by U. S. Public Health Service Research National Institutes of Health grants AM-16105 and AM-08469, by the Mayo Foundation, and by an established Investigator award (74-182) of the American Heart Association to Dr. Thomas P. Dousa. Brian A. Jackson, Ph.D., is the recipient of a Burroughs-Wellcome/National Kidney Foundation Research Fellowship. Richard M. Edwards conducted this research in partial fulfillment of the requirements for the Ph.D. degree in physiology, Mayo Graduate School of Medicine.

\section{REFERENCES}

1. Falconer, D. S., M. Latyszewski, and J. H. Isaacson. 1964. Diabetes insipidus with oligosyndactyly in the mouse. Genet. Res. 5: 473-488.

2. Naik, D. V., and H. Valtin. 1969. Hereditary vasopressinresistant urinary concentrating defects in mice. Am. J. Physiol. 217: 1183-1190.

3. Kettyle, W. M., and H. Valtin. 1972. Chemical and dimensional characterization of the renal countercurrent system in mice. Kidney Int. 1: 135-144.

4. Dousa, T. P., and H. Valtin. 1974. Cellular action of anti- diuretic hormone in mice with inherited vasopressin resistant urinary concentrating defects. J. Clin. Invest. 54: 753-762.

5. Dousa, T. P., and H. Valtin. 1976. Cellular actions of vasopressin in the mammalian kidney. Kidney Int. 10: 46-63.

6. Grantham, J. J., and M. B. Burg. 1966. Effect of vasopressin and cAMP on permeability of isolated collecting tubules. Am. J. Physiol. 211: 255-259.

7. Hall, D. A., L. D. Barnes, and T. P. Dousa. 1977. Cyclic AMP in action of antidiuretic hormone: effects of exogenous cyclic AMP and its new analogue. Am. J. Physiol. 232: $368-376$.

8. Hall, D. A., and D. M. Varney. 1979. Vasopressin-responsiveness of isolated perfused mouse cortical collecting tubules. Clin. Res. 27: 416A. (Abstr.)

9. Dousa, T. P. 1976. Some aspects of the cellular action of antidiuretic hormone in normal mammalian kidney and in nephrogenic diabetes insipidus. In Membranes and Disease. L. Bolis, J. F. Hoffman, and A. Leaf, editors. Raven Press, New York. 301-310.

10. Valtin, H., H. W. Sokol, and D. Sunde. 1975. Genetic approaches to the study of the regulation and actions of vasopressin. Recent Prog. Horm. Res. 31: 477-486.

11. Morel, M., D. Chabardès, and M. Imbert-Teboul. 1976. Methodology for enzymatic studies of isolated tubular segments: adenylate cyclase. Methods Pharmacol. 4B: $297-323$.

12. Jackson, B. A., R. M. Edwards, and T. P. Dousa. 1980. Measurements of cyclic AMP and cyclic GMP phosphodiesterase activity in isolated tubular segments. Kidney Int. In press.

13. Edwards, R. M., B. A. Jackson, and T. P. Dousa. 1980. Protein kinase activity in isolated tubules of rat renal medulla. Am. J. Physiol. 238: F269-F278.

14. Edwards, R. M., B. A. Jackson, and T. P. Dousa. 1979. Differential effect of vasopressin (VP) on adenylate cyclase activity and on cyclic AMP levels in medullary thick ascending limb of Henle's loop (MAL) in rat and mouse. Kidney Int. 16: 812. (Abstr.)

15. Chabardès, D., M. Imbert-Teboul, M. Gagnan-Brunette, and F. Morel. 1978. Different hormonal target sites along the mouse and rabbit nephrons. Curr. Prob. Clin. Biochem. 8: 447-454.

16. Morel, F., D. Chabardès, and M. Imbert-Teboul. 1978. Heterogeneity of hormonal control in the distal nephron. Proceedings VIIth International Congress of Nephrology. Montreal, Karger, Basel. 209-216.

17. Hall, D. A. 1979. Possible role of vasopressin in regulating solute transport in mouse medullary thick ascending limb of Henle's loop. Clin. Res. 27: 416A. (Abstr.)

18. Sasaki, S., and M. Imai. 1980. Effects of vasopressin on water and $\mathrm{NaCl}$ transport across the in vitro perfused medullary thick ascending limb of Henle's loop of mouse, rat, and rabbit kidneys. Pfluegers Arch. Eur. J. Physiol. 383: $215-221$.

19. Hall, D. A. 1979. Effect of vasopressin on chloride transport by mouse medullary thick ascending limb of Henle's loop perfused in vitro. Kidney Int. 16: 818. (Abstr.)

20. Imbert-Teboul, M., D. Chabardès, M. Montegut, A Clique, and F. Morel. 1978. Vasopressin-dependent adenylate cyclase activities in the rat kidney medulla: evidence for two separate sites of action. Endocrinology. 102: $1254-1261$.

21. Brunette, M. G., D. Chabardès, M. Imbert-Teboul, A. Clique, M. Montegut, and F. Morel. 1979. Hormone sensitive adenylate cyclase along the nephron of genetically hypophosphatemic mice. Kidney Int. 15: 357-369. 
22. Salomon, Y., C. Londos, and M. Rodbell. 1974. A highly sensitive adenylate cyclase assay. Anal. Biochem. 58: 541-548.

23. Torres, V. E., Y. S. F. Hui, S. V. Shah, T. E. Northrup, and T. P. Dousa. 1978. Cyclic nucleotide phosphodiesterases in glomeruli of rat renal cortex. Kidney Int. 14: 444-451.

24. Wells, J. N., C. E. Baird, Y. J. Wu, and J. G. Hardman. 1975. Cyclic nucleotide phosphodiesterase activities of pig coronary arteries. Biochim. Biophys. Acta. 384: 430-442.

25. Meyer, S. E., J. T. Stull, and W. B. Wastilla. 1974. Rapid tissue fixation and extraction techniques. Methods Enzymol. 38: 3-9.

26. Torres, V. E., T. E. Northrup, R. M. Edwards, S. V. Shah, and T. P. Dousa. 1978. Modulation of cyclic nucleotides in isolated rat glomeruli. Role of histamine, carbamylcholine, parathyroid hormone, and angiotensin-II. J. Clin. Invest. 62: 1334-1343.

27. Shah, S. V., T. E. Northrup, Y. S. F. Hui, and T. P. Dousa. 1979. Action of serotonin (5-hydroxytryptamine) on cyclic nucleotides in glomeruli of rat renal cortex. Kidney Int. 15: $463-472$.

28. Frandsen, E. K., and G. Krishna. 1976. A simple ultrasensitive method for the assay of cyclic AMP and cyclic GMP in tissues. Life Sci. 18: 529-542.

29. Lowry, O. H., N. J. Rosenbrough, A. L. Farr, and R. J. Randall. 1951. Protein measurement with folin phenol reagent. J. Biol. Chem. 193: 265-275.

30. Brenner, B. M., F. H. Falchuk, R. I. Keimowitz, and R. W. Berliner. 1969. The relationship between peritubular capillary protein concentration and fluid reabsorption by the renal proximal tubule. J. Clin. Invest. 48: 1519-1531.

31. Fine, L. G., D. Schlondorff, W. Trizna, R. M. Gilbert, and N. S. Bricker. 1978. Functional profile of the isolated uremic nephron. Impaired water permeability and adenylate cyclase responsiveness of the cortical collecting tubule to vasopressin. J. Clin. Invest. 61: 1519-1527.

32. Imbert-Teboul, M., D. Chabardès, M. Montegut, A. Clique, and F. Morel. 1978. Impaired response of adenylate cyclase of the thick ascending limb of Henle's loop in Brattleboro rats with diabetes insipidus. Renal Physiol. (Basel). 1: 3-10.
33. Drezner, M. K., and W. M. Burch, Jr. 1978. Altered activity of the nucleotide regulatory site in the parathyroid hormone-sensitive adenylate cyclase from the renal cortex of a patient with pseudohypoparathyroidism. J. Clin. Invest. 62: 1222-1227.

34. Moss, J., and M. Vaughan. 1979. Activation of adenylate cyclase by choleragen. Annu. Rev. Biochem. 48: 581-600.

35. Knepper, M. A., R. A. Danielson, G. M. Saidel, and R. S. Post. 1977. Quantitative analysis of renal medullary anatomy in rats and rabbits. Kidney Int. 12: 313-323.

36. Morel, F. 1964. Action of neurohypophysial hormones on the active transport of sodium. Water Electrolyte Metab. Proc. Symp. 2: 91-113.

37. Grantham, J. J. 1974. Action of antidiuretic hormone in the mammalian kidney. In Kidney and Urinary Tract Physiology. K. Thurau, editor. University Park Press, Baltimore, Md. 6: 247-272.

38. Abramow, M. 1974. Effects of ethacrynic acid on the isolated collecting tubule. J. Clin. Invest. 53: 796-804.

39. Chabardès, D., M. Gagnan-Brunette, M. Imbert-Teboul, O. Gontcharevskaia, M. Montegut, A. Clique, and F. Morel. 1980. Adenylate cyclase responsiveness to hormones in various portions of the human nephron. J. Clin. Invest. 65: 439-448.

40. Jard, S., C. Roy, T. Barth, R. Rajerison, and J. Bockaert. 1975. Antidiuretic hormone sensitive kidney adenylate cyclase. Adv. Cyclic Nucleotide Res. 5: 31-52.

41. Kim, J. K., B. A. Jackson, R. M. Edwards, and T. P. Dousa. 1979. Vasopressin (VP)-sensitive cyclic AMP (cAMP) system in medullary ascending limb of Henle's loop (MAL) and medullary collecting tubule (MCT) in potassium depletion. Kidney Int. 16: 784. (Abstr.)

42. Katz, A. I., A. Doucet, and F. Morel. 1979. Na-K-ATPase activity along the rabbit, rat and mouse nephron. Am.J. Physiol. 237: F112-F120.

43. Jackson, B. A., and T. P. Dousa. 1980. Adenylate cyclase (AdC) and cAMP-phosphodiesterase (cAMP-PDIE) in medullary tubules of rats with lithium $(\mathrm{Li})$-induced polyuria. Clin. Res. 28: 449A. (Abstr.)

44. Strada, S. J., and W. J. Thompson. 1978. Multiple forms of cyclic nucleotide phosphodiesterase: anomalies or biologic regulators. Adv. Cyclic Nucleotide Res. 9: 265-283. 